\title{
マクロライド系抗生剤のヒト副鼻腔粘膜線毛運動に及ぼす影響
}

\author{
田代 亨・竹野 幸夫・上田 直之 \\ 工田 昌矢・平川 勝洋・夜陣 紘治

\section{Stimulatory Effect of Macrolides on Mucociliary Activity in Cultured Human Sinus Ciliated Cells}

\author{
Toru Tashiro, Sachio Takeno, Naoyuki Ueda, \\ Masaya Takumida, Katsuhiro Hirakawa and Koji Yajin \\ (Hiroshima University School of Medicine)
}

\begin{abstract}
A number of recent reports have demonstrated that long-term low-dose macrolide therapy is effective on in the treatment of chronic sinusitis as well as diffuse panbronchiolitis. In this study, we focused on the in vitro effects of macrolides on the ciliary beat frequency (CBF) of cultured human sinus epithelial cells. Sinus mucosal explants were successfully cultured on poly-L-lysine coated dishes with abundant outgrowthal ciliated cells. CBF measurements were carried out by a photoelectric method at specific predetermined sites on the 7 to 14 day cultured specimens. Both erythromycin (EM) and roxithromycin (RXM) had no significant effects on $\mathrm{CBF}$ at a relatively high concentrations $\left(10^{-4} \mathrm{M}\right)$. However, EM and RXM, at a concentration of $10^{-5} \mathrm{M}$, significantly increased $\mathrm{CBF}$ by $20 \%$ and $19 \%$ respectively four hours after administration. The cilio-stimulatory effects continued to the same degree for 24 hours. We further subdivided the ciliated cells into two groups on the basis of their mucociliary activity, predetermined before drug administration. The faster group included cells with a CBF of more than 630 beat/min and the slower group included those with a $\mathrm{CBF}$ of less than 630 beat/min. Interestingly, both EM and RXM at concentrations of $10^{-4} \mathrm{M}$ and $10^{-5} \mathrm{M}$ showed no effect in the faster group. On the other hand, these drugs significantly increased the $\mathrm{CBF}$ of the ciliated cells in the slower group at both concentrations tested by a maximum of $34 \%$ with EM and 55\% with RXM. These results suggest that macrolide antibiotics augment the ciliary clearance of human parnasal sinuses, and that this effect might be more pronounced when the epithelial ciliated cells are in somewhat disturbed conditions.
\end{abstract}

Key words : macroride antibiotics, paranasal sinus, ciliary beat frequency, outgrowth culture, photoelectric method

はじめに

現在の抗生物質の開発と進歩には, めざましいものが ある.1952年に，McGuire らによって発見されたェリ スロマイシンが，ペニシリンが無効である細菌感染症に 対する抗生物質として登場してから，既に40年の歳月を 経た。このエリスロマイシンを代表とする14員環マクロ
ライド系抗生剤は，難治性の肺疾患であるびまん性汎細 気管支炎 (DPB) に対する有効性が工藤らにより報告さ れて以来 ${ }^{11}$, 同じ上気道感染症である慢性副鼻腔炎にも 同療法が応用されて広く現在に至っている233)。その有 効機序としては，抗菌作用の他に，炎症性サイトカイン 産生の制御と浸潤するリンパ球への作用, 鼻汁の過分泌 
に対する抑制効果，線毛運動の賦活化作用など，さまざ まな作用が提唱されている4) -6)。この中でも線毛運動の 賦活化作用は，副鼻腔粘膜を含む上気道粘膜上皮に拈け るバリアーを構成する因子として非常に重要であると言 える.今回我々はこの作用に着目し，本機序の解明を目 的として培養副鼻腔粘膜上皮を用いて実験を行った。す なわち14員環マクロライド系抗生剤であるェリスロマイ シン $(\mathrm{EM})$ ならびにロキシスロマイシン $(\mathrm{RXM}) を$ を, 初 代培養線毛細胞に作用させ，その単一線毛細胞における 線毛打頻度 $(\mathrm{CBF})$ の変化を経時的に観察した．同時に 薬物添加前の CBF の值により, 線毛細胞を“早い”群 と“遅い”群に二分し，それぞれの群において CBF の 変化がどのよらであるかを比較検討した。

\section{実験方法}

慢性副鼻腔炎手術時に採取した，ヒト上顎洞または篩 骨洞粘膜 7 例を用いた．採取した粘膜は生理食塩水で付 着した血液を洗い, phosphate buffered saline (PBS)に て洗浄した後, 約 $5 \mathrm{~mm}$ 四方にトリミングした。これを 移植片 (explant) として，上皮側が上向きになるように poly-L-lisine コーティングしたプラスティックシャーレ 上で初代培養を行った。培地組成は $300 \mathrm{mOsm}$ に浸透 圧を調整した D-MEM (GIBCO BRL，東京)に 10\% FBS (Sigma, St. Louis，MO) と抗生物質を添加したものを 用いた。 また細胞接着の促進のため培養支持器材には poly-L-lysine をコーティングしたシャーレ(セルタイト C-I，PL，スミロン，東京)を用いた. $95 \%$ air， $5 \% \mathrm{CO}_{2}$ 条件下で培養を行い, explant 周囲に派生した outgrowth 上皮が観察される $5 \sim 7$ 日のものを実験対象とした. Outgrowth 細胞に抢ける上皮の同定は, 試料の一部を $4 \%$ パラホルムアルデヒドにて固定し，上皮のマーカー であるサイトケラチンに対する免疫染色を施行すること により行った.

outgrowth sheet 上に存在している線毛細胞の CBF の測定は NIKON photometry system P100を用いて行 い，20倍の対物レンズを用い位相差顕微鏡下にて，同一 の単一細胞に扣ける薬剤負荷前後の $\mathrm{CBF}$ 変化を継時的 に計測した（図 1 )。温度設定は $37^{\circ} \mathrm{C}$ の恒温条件下とし た。薬剤刺激としてはェリスロマイシン並びにロキシス ロマイシン (Sigma) を $10^{-4} \mathrm{M}$ と $10^{-5} \mathrm{M}$ の最終濃度に なるように培地に添加し，添加直前， 1 時間後， 4 時間 後, 24時間後の単一線毛細胞の CBF を測定した. コン
トロールとしては同量の PBSを添加したものを用いた. また今回の検討では, 線毛細胞群を処置前の CBF が 630 beat $/ \mathrm{min}$ 未満の遅い線毛細胞群と, CBF が 630 beat $/ \mathrm{min}$ 以上の早い線毛細胞群の 2 群に分類し，それぞれ の群においてマクロライド薬剤がどのよらに影響するか 比較検討した。また予備実験として outgrowth 上の線 毛細胞の部位による $\mathrm{CBF}$ の相違, すなわち explant 周 囲から離れるに従って $\mathrm{CBF}$ 平均がどのよらに変化して いるかの検討も行った。

\section{結 果}

図 1 (a) は代表的な outgrowth sheet 上の培養細胞の サイトケラチンに対する蛍光免疫染色画像, 図 1 (b) は outgrowth 上の線毛細胞の各部位に拈ける CBF の相違 を示したものである。培養細胞は敷石状配列を呈し，そ のほとんどがサイトケラチンに対して陽性所見を示した. また予備実験として検討した，コントロール群における outgrowth 部位における線毛細胞の CBF の变化に関し ては, explant 周囲の領域に比較して outgrowth 中央部 と辺縁部では, 有意に CBF の低下が観察された. 今回 は explant 周囲の線毛細胞を対象とし, 薬剤刺激後の変 化を検討した。

次に線毛細胞の $\mathrm{CBF}$ の薬剤刺激前後における経時的 変化について検討した. 図2 にはコントロール群におけ る $\mathrm{CBF}$ の継時的変化を示している. 本群に打いて $\mathrm{CBF}$ は24時間後まで平均 $610 \sim 682$ beat/min とほぼ安 定して扣り, 統計的に有意差を認めなかった。 図 3 と図 4 には，EM $\left(10^{-4} \mathrm{M}, 10^{-5} \mathrm{M}\right)$ および RXM $\left(10^{-4} \mathrm{M}\right.$, $\left.10^{-5} \mathrm{M}\right)$ にて薬剂刺激を行った後の $\mathrm{CBF}$ の経時的变化 を示している。な扮縦軸は, 薬剤刺激直前を $100 \%$ と た相対的变化率で表している．EM， RXM ともに $10^{-4}$ $\mathrm{M}$ の濃度では24時間後に至るまで, $\mathrm{CBF}$ 変化率に有意 差を認めなかった。しかしながら $10^{-5} \mathrm{M}$ の濃度では, $\mathrm{EM}, \mathrm{RXM}$ とも 4 時間後より約 $20 \%$ の割合で有意の $\mathrm{CBF}$ の上昇を認め 24 時間後に抢いてもこの作用は持続 していた.

今回の実験では, 刺激前の線毛細胞における線毛運動 活性の状態により, マクロライドの影響がどのように異 なるかについての検討も行った。すなおち，刺激前の $\mathrm{CBF}$ が 630 beat $/ \mathrm{min}$ 未满の “遅い”線毛細胞群と, 630 beat $/ \mathrm{min}$ 以上の “早い” 線毛細胞群の 2 群にあらかじ め分類し, EM および RXM による賦活作用の違いを比 


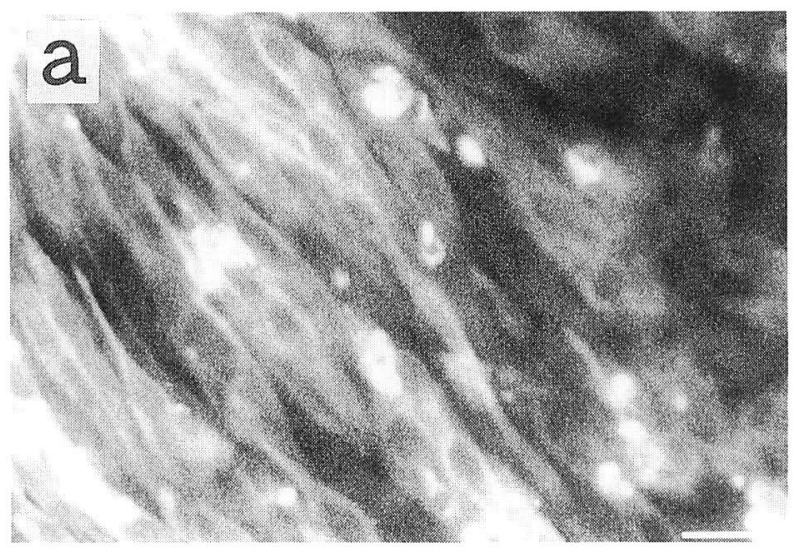

a

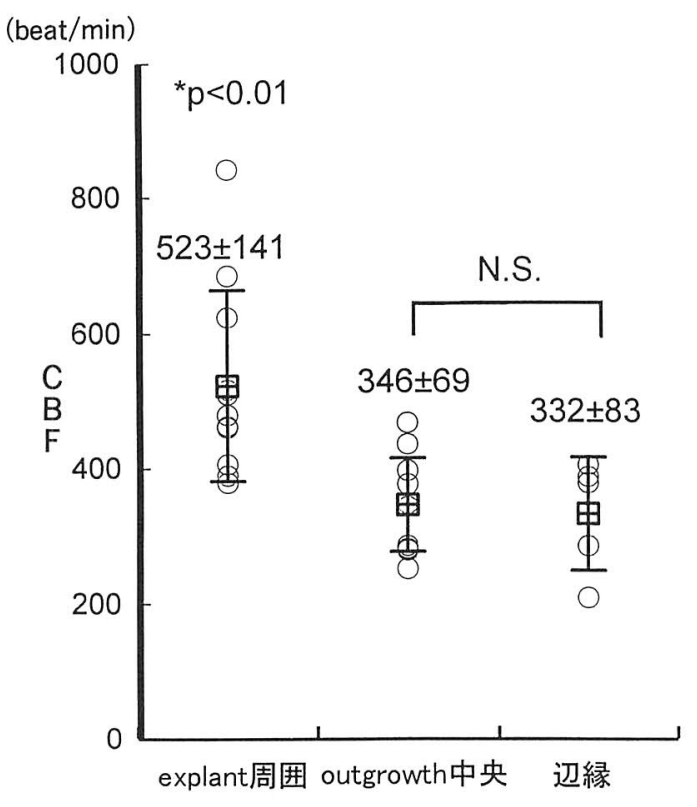

b

図 1 a ）培責篩骨洞粘膜 outgrowth 上皮に打けるサイトケ ラチン免疫染色像 (培養 7 日目, 共焦点レーザー顕 微鏡写真).

b）outgrowth 上の単一線毛細胞の培着部位に抽ける $\mathrm{CBF}$ の変化(培養 5 日目, 無処置状態).

較した。図 5 には (a) EM $10^{-4} \mathrm{M}$ ， (b) EM 10-5 M によ る $\mathrm{CBF}$ の変化率を示している. この中で早い線毛細胞 群は，24時間後に至るまで CBF に有意な変化を認めな かった。しかしながら遅い線毛細胞群は EM 10-4 M で は24時間後で, EM $10^{-5} \mathrm{M}$ では 4 時間後より線毛活性 の上昇が認められて拈り, 図 3 で示した全体の CBF の 賦活作用は主として遅い線毛細胞に対する作用であるこ とが推察された．図 6 には同様に (a) RXM $10^{-4} \mathrm{M}$ ， (b)

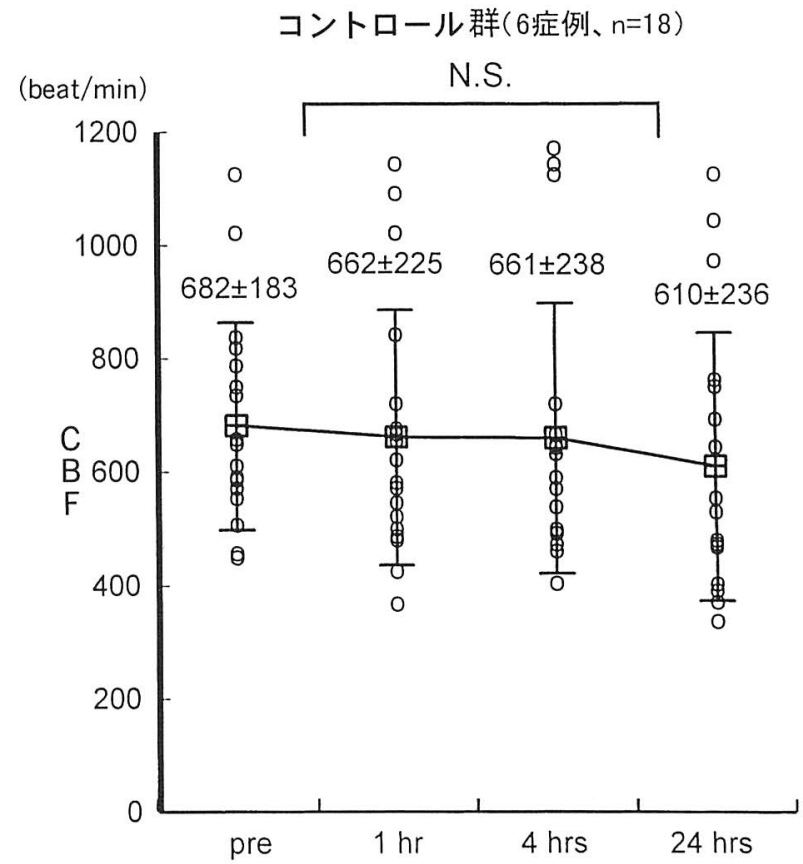

図 2 コントロール群に和ける $\mathrm{CBF}$ の経時的変化.

$\mathrm{RXM} 10^{-5} \mathrm{M}$ による $\mathrm{CBF}$ の変化率を示している，EM と同様に早い線毛細胞群は，24時間後に至るまで CBF に有意な変化を認めなかった。しかしながら遅い線毛細 胞群は RXM $10^{-4} \mathrm{M} ， 10^{-5} \mathrm{M}$ ともに 4 時間後より線毛 活性の上昇が認められて括り，24時間後もとの作用の持 続が認められた。

\section{考察}

マクロライド系抗生剤と CBF に関する過去の報告で は, 1991年に玉置らが家鬼培養気管上皮に扣いて，RXM は用量依存的に CBF の増加を認め，特に $10^{-4.5} \mathrm{M}$ の投 与により，最大 $34.6 \%$ の増加を認めたと報告している. その際, 気道上皮細胞内の cAMP 濃度の上昇を伴なっ て扣り，これらの作用はシクロオキシゲナーゼ阻害剤で あるインドメサシンで抑制されたと述べている5)。また， 1995年に森らは正常ヒト篩骨洞粘膜より採取した線毛細 胞に扮いて，10-5 M 大 $21.2 \%$ CBF の増加作用を認めている。 またこの賦 活作用は薬剂刺激後 $1 \sim 2$ 時間後に最大となり, 高濃度 よりむしろ低濃度のマクロライドで亢進作用は著明であ ったと報告している7)。一方, 慢性副鼻腔炎による粘液 線毛輸送系の障害について，1991年 Ohashi らは採取し 


\section{(a) EM $10^{-4}$ M群}

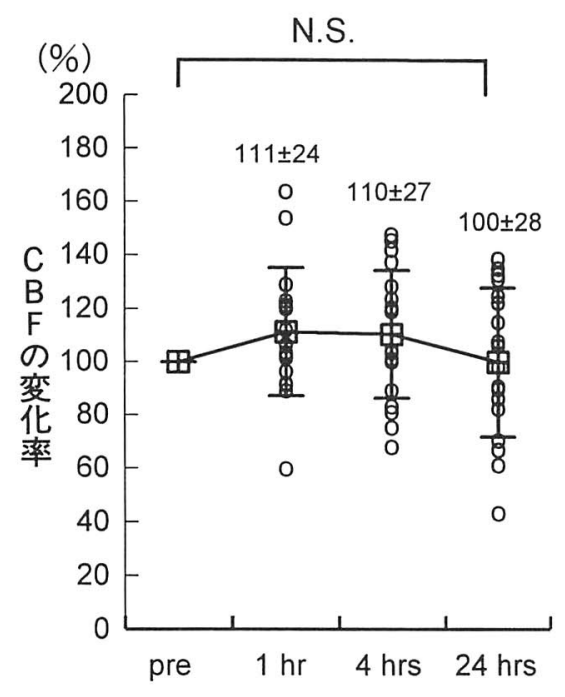

(b) EM $10^{-5}$ M群

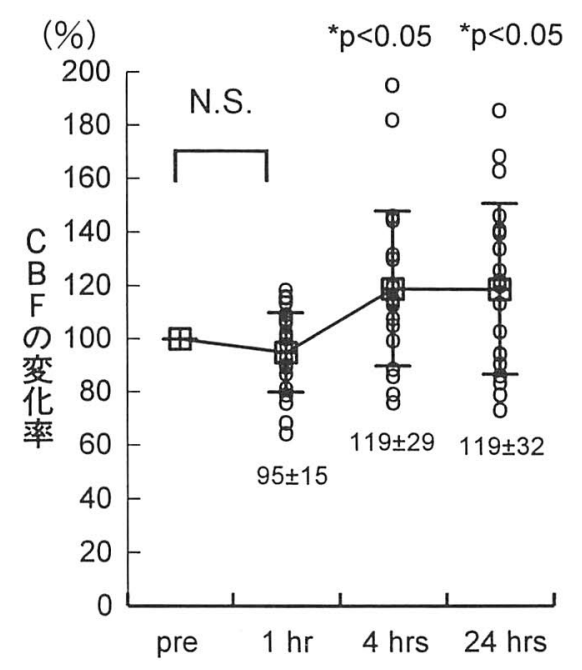

図 3 a ) $\mathrm{EM} 10^{-4} \mathrm{M}$ とb) $\mathrm{EM} 10^{-5} \mathrm{M}$ とよる CBF の変化.

(a) RXM 10-4M群

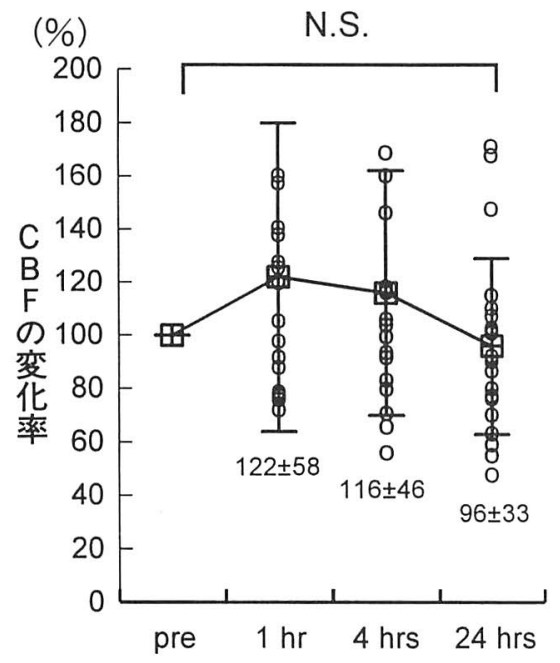

(b) RXM 10-5M群

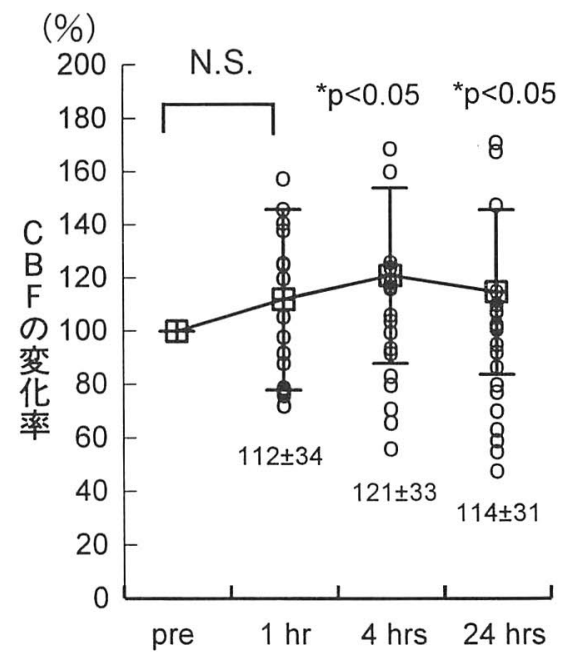

図 4 a ) RXM $10^{-4} \mathrm{M}$ とb) RXM $10^{-5} \mathrm{M}$ による $\mathrm{CBF}$ の変化.

た粘膜の走査電顕による観察と CBF の測定により評価 を行っている8). それによると CBF が 400 beat $/ \mathrm{min}$ 未 満の症例では, 形態学的にも上皮細胞の高度脱落や構築 の変化が生じて招り, 保存的治療に上る可逆性は期待で きず手術適応と考光られるが, CBF が 400 beat $/ \mathrm{min}$ 以 上の場合は上皮細胞の形態学的な変化は少なく, マク口 ライドなどの薬物療法によっても, 病態が改善される可
能性があると述べている.

今回の我々の検討では, 慢性副鼻腔炎時の副鼻腔粘膜 に扣いても, 先に述べた玉置, 森らの報告と同様にマク ロライドによる $\mathrm{CBF}$ の充進作用があり，この交進作用 は, EM, RXM ともに $10^{-4} \mathrm{M}$ よりむしろ $10^{-5} \mathrm{M}$ で顕 著であった。この $10^{-5} \mathrm{M}$ といら濃度は, 実際の臨床に 护ける薬剤の組織移行性とほぼ矛盾しないものと考光ら 
(a) EM 10-4M群
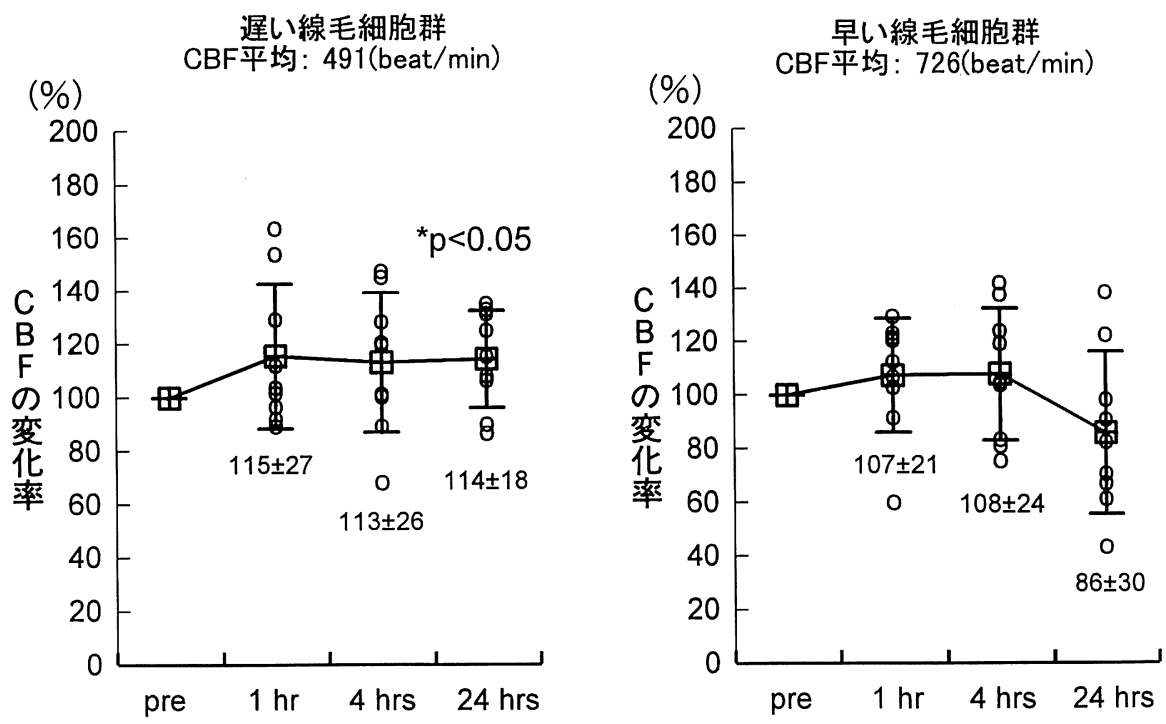

(b) EM $10^{-5}$ M群

遅い線毛細胞群

CBF平均: 545 (beat $/ \mathrm{min}$ )
早い線毛細胞群

CBF平均: 788(beat $/ \mathrm{min}$ )
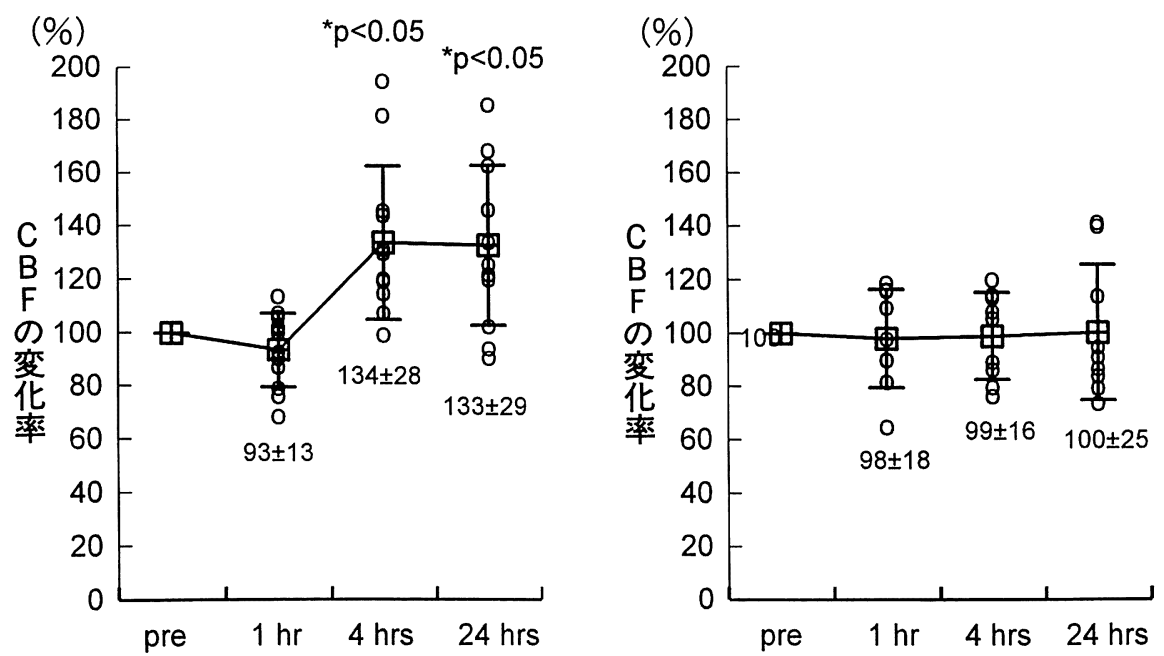

図 5 遅い線毛細胞群と早い線毛細胞群のそれぞれに対する a ) EM $10^{-4} \mathrm{M}$ とb） $\mathrm{EM} 10^{-5} \mathrm{M}$ の効果.

れる9．さらに Ohashi らの報告も含めて考察すると， 個々の線毛細胞に括いて，CBF が少なくとも 630 beat/ $\min$ に達しないものであっても, 病態の障害は可逆的で あり，マクロライドによる線毛運動の賦活作用が期待で きることを示しているものと思われる.
またこれらの元進作用は, 薬剤刺激後 4 時間以降に認 められた．効果発現までに長時間を要したのは，線毛上 皮の外層粘液に括ける網状構造が，投与された薬物と短 時間に混和することなく長時間をかけて徐々に混和し， その網状構造内に溶媒を取り込むといら性質も関与して 
(a)RXM 10-4M群
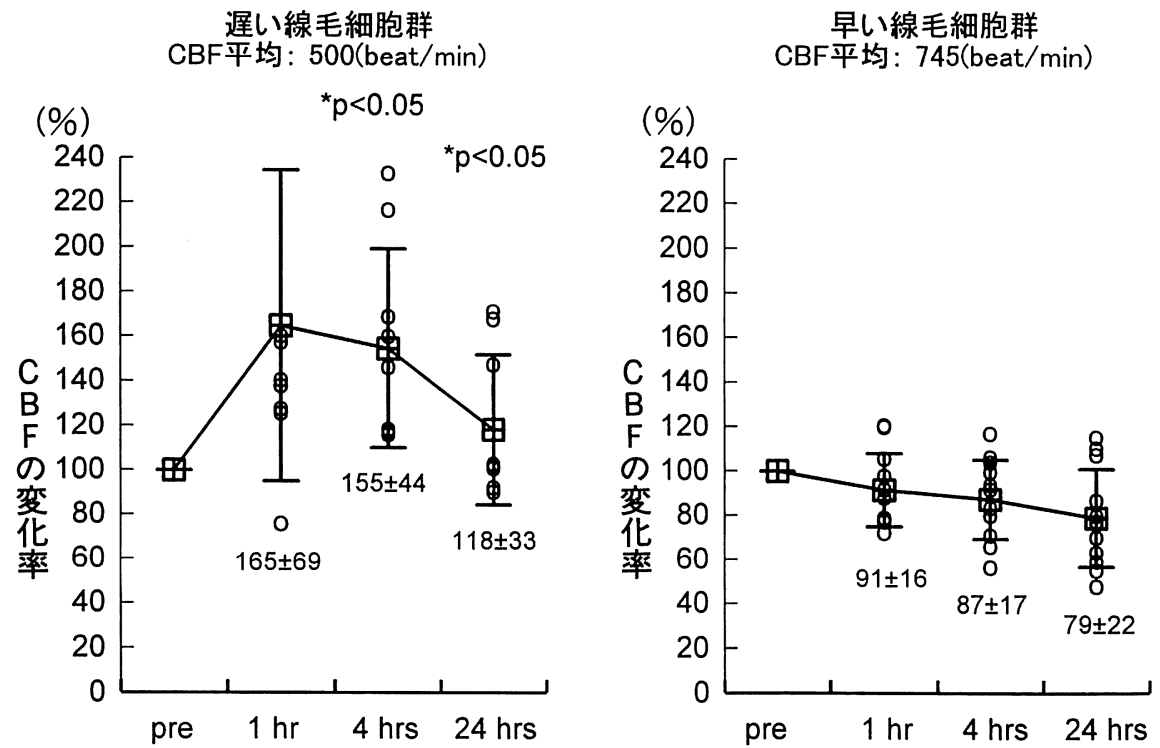

(b) RXM 10-5M群

遅い線毛細胞群

CBF平均: 476 (beat $/ \mathrm{min}$ )

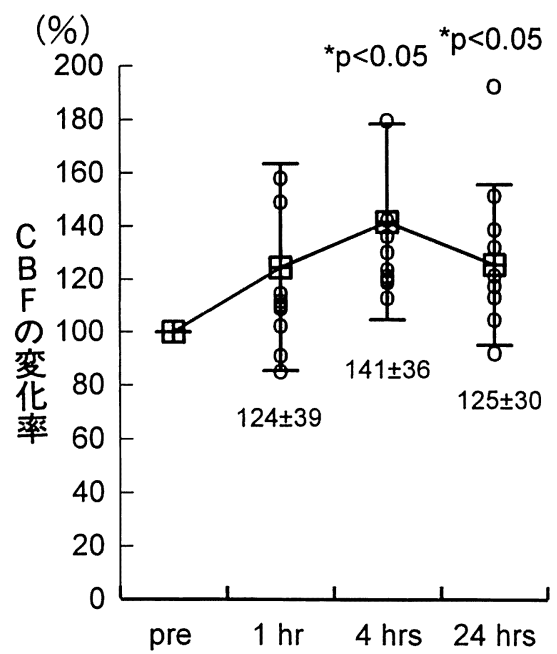

早い線毛細胞群

CBF平均: 782 (beat $/ \mathrm{min}$ )

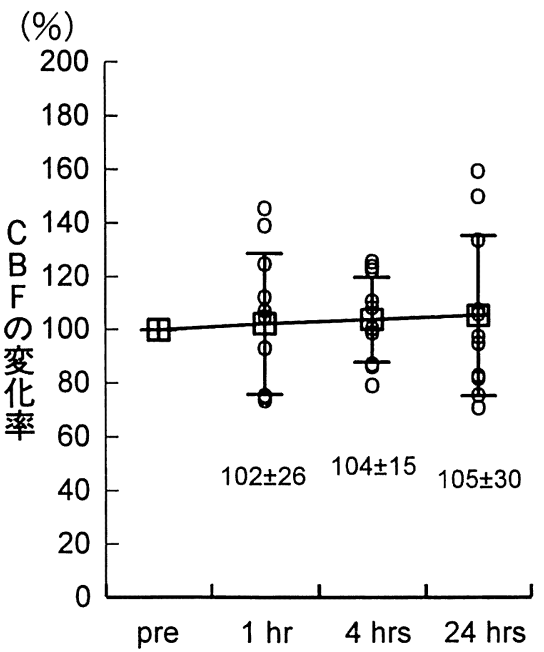

図 6 遅い線毛細胞群と早い線毛細胞群のそれぞれに対する a ) RXM $10^{-4} \mathrm{M}$ と b ) $\mathrm{RXM} 10^{-5} \mathrm{M}$ の効果.

いると考えられる．またこの気道表面夜のゾル層の調節 には，気道上皮細胞の管腔側に存在するクロライドチャ ネルが深く関与していると言われている．興味深いこと に，マクロライドはクロライドチャネルを直接的に抑制 するとされて扣り，これにより気道過分泌の制御に働く
作用も有している ${ }^{10)}$ 。また，この CBF の六進作用は， 処置前の $\mathrm{CBF}$ が遅い線毛細胞群に限られており, $\mathrm{CBF}$ の早い線毛細胞群には有意差が認められなかった。この 理由に関しては現在の所はっきりしていないが，マクロ ライド剤の慢性副鼻腔炎に対する有効機序の本質に関わ 
るものと思われるため, 今後更に検討していきたいと考 えている.

\section{結 語}

エリスロマイシン $(\mathrm{EM})$ 並びにロキシスロマイシン (RXM)を $10^{-4} \mathrm{M}, \quad 10^{-5} \mathrm{M}$ の濃度にて, 副鼻腔炎患者 より採取した培養ヒト上顎洞または篩骨洞粘膜の線毛細 胞に作用させ, 線毛打頻度 $(\mathrm{CBF})$ の経時的变化を, 薬 剂刺激直前を $100 \%$ とした経時的変化率の形で検討し， 以下の結果を得た。

1) $\mathrm{EM}, \mathrm{RXM}$ ともに $10^{-4} \mathrm{M}$ では $\mathrm{CBF}$ の変化率で は有意差を認めなかったが，EM，RXM $10^{-5} \mathrm{M}$ では薬 剂添加後, 4 時間後と24時間後で有意な $\mathrm{CBF}$ の上昇を 認めた。

2 ）さらに全線毛細胞を, CBF が 630 beat $/ \mathrm{min}$ 未満 の遅い線毛細胞群と, $630 \mathrm{beat} / \mathrm{min}$ 以上の早い線毛細 胞群の 2 群に分類し, マクロライドの影響を検討したと ころ, 早い線毛細胞群ではすべての濃度において $\mathrm{CBF}$ の変化を認めなかった。一方, 遅い線毛細胞群では $\mathrm{EM} 10^{-4} \mathrm{M}$ で24時間後に EM $10^{-5} \mathrm{M}$ で 4 時間後より $\mathrm{CBF}$ の上昇が観察された。また RXM では $10^{-4} \mathrm{M}$ ， $10^{-5} \mathrm{M}$ ともに 4 時間後より $\mathrm{CBF}$ の上昇が認められ, 1 ) で観察された変化は主として遅い線毛細胞群に対す る作用によるものであることが，明らかとなった．

\section{参考文献}

1) 工藤翔二, 木村 仁, 植竹健二, 他 : びまん性汎細気管支 炎にたい寸るマクロライド系抗生剤の少量長期投与の臨床.
日胸疾会誌 増 $22: 252,1984$.

2 ) 菊地 茂, 洲崎春海, 青木彰彦, 他: 副鼻腔炎とェリス口 マイシン少量長期投与. 耳鼻臨床 $84: 41 \sim 47,1991$.

3 ) 高北晋一, 北村溥之, 大八木章博, 他 : 慢性副鼻腔炎と少 量エリスロマイシン療法. 耳鼻臨床 $84 ： 489 \sim 498,1991$.

4 ）三輪正人, 岩田重信, 高須昭彦, 他 : 培養気道上皮細胞管 腔側のクロライドチャネル活性に対するロキシスロマイシ ンの抑制効果. 耳展 39 補 $1: 23 \sim 27,1996$.

5 ) 玉置 淳, 武山 廉, 千代谷厚, 他: 気道粘膜上皮の線毛 運動に対するロキシスロマイシンの効果とその作用機序に 関する検討. 呼吸と循環 $39: 481 〜 485,1991$.

6 ) Suzuki H, Shimomura A, Ikeda K, et al : Inhibitory effect of macrolides on interleukin- 8 secretion from cultured human nasal epithelial cells. Laryngoscope $107: 1661 \sim$ 1666,1997

7 ) 森 繁人, 斎藤 等, 木村有一, 他: マクロライド系抗生 剤の鼻粘膜線毛運動に及ぼす影響. 耳展 38 補 $3: 220 \sim 227$, 1995.

8 ) Ohashi Y and Nakai T : Functional and morphological studies on chronic sinusitis mucous membrane (2) ; functional and morphological pathology of chronic sinusitis mucous membrane. Acta Otolaryngol (Stockh) Suppl $397: 11 \sim 48,1983$.

9 ) 石戸谷淳一, 増田哲也, 中井淳仁, 他 : RXM の少量長期 療法と鼻粘膜への組織移行. 耳鼻臨床 88 : 535 542, 1995.

10）高崎賢治, 吉見龍一郎, 高村博光, 他：鼻茸組織内の浸潤 細胞と RXM の影響. 耳鼻臨床 $87 ： 1643 \sim 1649,1994$.

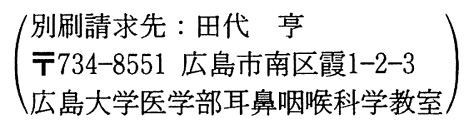

